\title{
The mechanism of acidic $\mathrm{pH}$-induced contraction in aortae from SHR and WKY rats enhanced by increasing blood pressure
}

\author{
${ }^{1}$ Ken-Ichi Furukawa, Junji Komaba, Hiroyuki Sakai \& Yasushi Ohizumi
}

Department of Pharmaceutical Molecular Biology, Faculty of Pharmaceutical Sciences, Tohoku University, Aoba, Aramaki, Aoba-ku, Sendai 980, Japan 1 Effect of $\mathrm{pH}$ on vascular smooth muscle contraction was analyzed by use of biochemical and
pharmacological techniques.

2 In the aorta isolated from spontaneously hypertensive rats (SHR) decreasing extracellular $\mathrm{pH}\left(\mathrm{pH}_{\mathrm{o}}\right)$ caused a rapid acidification of intracellular $\mathrm{pH}$ accompanied by a $\mathrm{pH}_{\mathrm{o}}$-dependent increase in tension. The contraction of the SHR aorta was remarkable compared with that of the Wistar Kyoto rat (WKY) aorta.

3 Removal of $\mathrm{NH}_{4} \mathrm{Cl}$ caused a transient decrease in intracellular $\mathrm{pH}$ followed by a marked increase in tension.

4 Both contraction and intracellular $\mathrm{Ca}^{2+}$ mobilization induced by acidic $\mathrm{pH}_{\mathrm{o}}$ were markedly inhibited by removal of extracellular $\mathrm{Ca}^{2+}$, verapamil and adenosine, whereas these were not affected by tetrodotoxin or $\mathrm{Gd}^{3+}$, a stretch-activated cation channel blocker. Furthermore, cromakalim $\left(\mathrm{a} \mathrm{K}^{+}\right.$ channel opener) inhibited acidic $\mathrm{pH}_{\mathrm{o}}$-induced contraction (APIC).

5 Acidic $\mathrm{pH}_{\mathrm{o}}$ induced a depolarization of cultured smooth muscle cells from SHR aorta.

6 Blood pressure elevated with increasing age of WKY and SHR accompanied by an increase in APIC. Feeding WKY with $\mathrm{N}^{\mathrm{G}}$-nitro-L-arginine, an inhibitor of nitric oxide synthases caused a marked elevation of their blood pressure followed by an increase in APIC.

7 These results suggest that APIC is caused by $\mathrm{Ca}^{2+}$ influx mediated through the activation of voltagesensitive $\mathrm{Ca}^{2+}$ channels mainly due to acidic $\mathrm{pH}_{\mathrm{o}}$-induced depolarization of the plasma membrane of smooth muscle cells. It is also suggested that APIC is strengthened by the elevation of blood pressure.

Keywords: Spontaneously hypertensive rats; vascular smooth muscle; hypertension; blood pressure; acidosis; $\mathrm{Ca}^{2+}$ mobilization; voltage-sensitive $\mathrm{Ca}^{2+}$ channel; $\mathrm{K}^{+}$channel; fura-2; $\mathbf{N}^{\mathrm{G}}$-nitro-L-arginine

\section{Introduction}

Contractions of vascular smooth muscle are initiated by an increase in intracellular $\mathrm{Ca}^{2+}$ concentrations $\left(\left[\mathrm{Ca}^{2+}\right]_{\mathrm{i}}\right)$ which follows various physiological stimuli (Somlyo, 1985). The contractile state can be modified by several factors including $\mathrm{pH}$. Ischaemia causes various disturbances including hypoxia and acidosis in the cirulatory system (Levine, 1993). Although physiological $\mathrm{pH}$ of body fluid is maintained at around 7.4, ischaemia easily decreases the $\mathrm{pH}$ value to 6.5 or lower (Butwell et al., 1993). Changes in extracellular $\mathrm{pH}\left(\mathrm{pH}_{\mathrm{o}}\right)$ affect intracellular $\mathrm{pH}\left(\mathrm{pH}_{\mathrm{i}}\right)$ (Yu et al., 1991; Austin \& Wray, 1993) and both $\mathrm{pH}_{\mathrm{o}}$ and $\mathrm{pH}_{\mathrm{i}}$ are known to alter vascular tone and thereby affect the circulation (Gaskell, 1980; Gardner et al., 1988; Danthuluri et al., 1989; Austin \& Wray, 1993). pH has an important function in the regulation of intracellular events, so acidosis may cause functional disorders. However, effects of $\mathrm{pH}$ on vascular smooth muscle in physiological and pathophysiological conditions have been unclear. Adenosine is thought to be produced and released from various tissues as an endogenous protective agent in ischaemia, but the detailed protective mechanism is unresolved (Rudolphi et al., 1993).

In spite of substantial studies including study of genes related to the disease, the mechanism that contributes to the aetiology and pathogenesis of essential hypertension remains unknown. The spontaneously hypertensive rat (SHR) is a useful model for studying mechanisms that may be responsible for essential hypertension. It has been reported that there are several functional abnormalities in vascular tissue of SHR compared to that of normotensive Wistar Kyoto rats (WKY)

\footnotetext{
${ }^{1}$ Author for correspondence.
}

(Asano et al., 1993; Batra et al., 1993; Clark et al., 1993; England et al., 1993; Jaiswal et al., 1993; Kuttan \& Sim, 1993; Le Jemtel et al., 1993; Orlov et al., 1993; Schirner \& Taube, 1993). Recent studies have revealed the abnormal $\mathrm{Na}^{+} / \mathrm{H}^{+}$ exchange in hypertension, suggesting the participation of abnormal pH control in the pathogenesis of hypertension (Rosskopf et al., 1993).

The present study was carried out to clarify the effects of acidic $\mathrm{pH}_{\mathrm{o}}$ on the rat thoracic aorta isolated from normo- and hypertensive rats. We have shown for the first time that the aorta from hypertensive rats is much higher sensitive to acidic $\mathrm{pH}_{\mathrm{o}}$ than that from normotensive rats and that there is a close correlation between the elevation of blood pressure and hypersensitive contractile response to acidic $\mathrm{pH}_{0}$. In addition, we discuss a possible mechanism of acidic $\mathrm{pH}_{\mathrm{o}}$-induced contraction of rat aorta. These results may contribute to the clarification of not only pathophysiological but also biochemical and physiological roles of $\mathrm{pH}$ in vascular smooth muscle functions.

\section{Methods}

\section{Recording of blood pressure}

The carotid arteries of rats were exposed and polyethylene tubes (PE 60; Clay Adams, Parsippany, U.S.A.) were inserted while under pentobarbitone anaesthesia $\left(40 \mathrm{mg} \mathrm{kg}^{-1}\right.$ body weight). The carotid arteries were connected to a pressure transducer (Nihon Koden, Tokyo, Japan) and the mean arterial blood pressures were recorded on a graph for at least 10 min until reaching a plateau. 


\section{Measurements of isometric contraction}

After recording the blood pressure, rats were killed by cervical dislocation. The thoracic aorta was dissected and connective tissues were carefully removed. The endothelium was removed by gently rubbing the endothelial surface with cotton pellets. The lack of endothelium was checked by the abolition of acetylcholine-induced relaxation. The aorta was cut into helical strips approximately $1.5-2 \mathrm{~mm}$ in width and $20 \mathrm{~mm}$ in length. One end of the strip was secured to the glass tissue holder by a silk ligature and the other end was connected to a force-displacement transducer. The strip was suspended in a $20 \mathrm{ml}$ organ bath containing HEPES-buffered Krebs solution of the following composition (mM): $\mathrm{NaCl} 120, \mathrm{KCl} 4.8$, $\mathrm{MgSO}_{4} 1.3$, glucose 5.8, $\mathrm{CaCl}_{2} 1.2, \mathrm{KH}_{2} \mathrm{PO}_{4} 1.2, \mathrm{NaHCO}_{3}$ 12.6, HEPES 10 . The solution was gassed with $95 \% \mathrm{O}_{2}: 5 \%$ $\mathrm{CO}_{2}$. $\mathrm{pH}$ of the solution was changed from a control value of 7.4 by addition of either $\mathrm{NaOH}$ or $\mathrm{HCl}$ and monitored from time to time with a handy type $\mathrm{pH}$ meter (Horiba, B-212). The tissues were equilibrated for $1 \mathrm{~h}$ under a resting tension of $1 \mathrm{~g}$. Isometric contraction was then measured by the transducer. The strip was precontracted 3 times by adding $\mathrm{KCl}$ (final concentration was $60 \mathrm{mM}$ ). There was no significant difference in responses to $\mathrm{KCl}(60 \mathrm{mM})$ between hypertensive (SHR and $\mathrm{N}^{\mathrm{G}}$-nitro-L-arginine-treated $\mathrm{WKY}$ ) and normotensive WKY rats. Therefore, we employed contraction induced by $\mathrm{KCl}$ $(60 \mathrm{mM})$ as an internal standard and acidic $\mathrm{pH}_{\mathrm{o}}$-induced contraction (APIC) have been normalized to the $\mathrm{KCl}$-induced contraction.

\section{Simultaneous measurements of $p H_{i}$ and contraction}

The fluorescent $\mathrm{pH}$ indicator dye, 2,7-bis(carboxyethyl)carboxyfluorescein (BCECF) was used to monitor changes in $\mathrm{pH}_{i}$. Spiral strips of aorta were loaded with BCECF by incubating with $10 \mu \mathrm{M}$ BCECF-acetoxymethylester for 3$5 \mathrm{~h}$ at $37^{\circ} \mathrm{C}$ in the same HEPES buffered-Krebs solution as described above except that a non-cytotoxic detergent, cremophor EL $(0.05 \%)$ was included. The strip was mounted horizontally in a bath $\left(5 \mathrm{ml}, 37^{\circ} \mathrm{C}\right)$ attached to a fluorimeter (CAF-100, Japan Spectroscopic, Tokyo, Japan). Contraction and BCECF fluorescence (excitation at 440 and $500 \mathrm{~nm}$, emission at $530 \mathrm{~nm}$ ) were measured simultaneously. To calculate the $\mathrm{pH}_{\mathrm{i}}$ the ratio of two fluorescence intensities (R500/ 440 ) was calibrated using nigericin $\left(6 \mathrm{mg} \mathrm{m}^{-1}\right)$ in $120 \mathrm{mM} \mathrm{K}^{+}$ buffer as described previously (Kurtz \& Golchini, 1987).

\section{Simultaneous measurements of $\left[\mathrm{Ca}^{2+}\right]_{i}$ and contraction}

The level of cytoplasmic $\mathrm{Ca}^{2+}$ was monitored by use of fura- 2 as a fluorescent $\mathrm{Ca}^{2+}$ indicator. Spiral strips of aorta were loaded with fura- 2 by incubating with $20 \mu \mathrm{M}$ fura-2-acetoxymethylester for $3-5 \mathrm{~h}$ at $37^{\circ} \mathrm{C}$ in HEPES-buffered Krebs solution including cremophor EL $(0.05 \%)$. After the strip was mounted horizontally in a bath $\left(5 \mathrm{ml}, 37^{\circ} \mathrm{C}\right)$ attached to a fluorimeter (CAF-100, Japan Spectroscopic, Tokyo, Japan), contraction and fura-2 fluorescence were measured simultaneously. The intensities of $500 \mathrm{~nm}$ fluorescence induced by excitation at $340 \mathrm{~nm}$ (F340) and 380 (F380) were measured. The ratio of these two fluorescence values (R340/380) was calculated as an indicator of the relative cytosolic $\mathrm{Ca}^{2+}$ level. The absolute $\left[\mathrm{Ca}^{2+}\right]_{\mathrm{i}}$ was not calculated because the dissociation constant of fura- 2 and $\mathrm{Ca}^{2+}$ in cytosol may be different from that obtained in vitro (Karaki, 1989; Mitsui \& Karaki, 1990).

\section{Measurement of membrane potential of primary cultured vascular smooth muscle cells}

Vascular smooth muscle cells (VSMCs) were isolated from rat aorta $(250-300 \mathrm{~g}$, SHR male rat) by enzymatic dispersion as described by Chamley et al. (1977). The resulting cells were seeded onto sterile glass cover slips laid in a $100 \times 100 \mathrm{~mm}$ square dish for measurements of membrane potential. The cells were cultured for 4 to 5 days in Dulbecco's modified Eagle's medium supplemented with $10 \%$ heat-inactivated foetal calf serum, 10 units $\mathrm{ml}^{-1}$ penicillin, and $100 \mu \mathrm{g} \mathrm{ml}^{-1}$ streptomycin. After reaching confluency, cells were cultured in serum-free medium (Cosmedium 001) for additional $24 \mathrm{~h}$ to enhance differentiation. Membrane potential changes were monitored with a potential-indicator dye diS- $\mathrm{C}_{3}(5)(\mathrm{Sims}$ et al., 1974; Furukawa et al., 1991) under conditions similar to those used for measurement of contraction. Cultured smooth muscle cells attached to glass coverslips were preincubated with $0.5 \mu \mathrm{M} \mathrm{diS}-\mathrm{C}_{3}(5)$ at $37^{\circ} \mathrm{C}$ for $5 \mathrm{~min}$ in PBS before assaying fluorescence. Fluorescence measurements were carried out with excitation at $620 \mathrm{~nm}$ and emission at $680 \mathrm{~nm}$, respectively, in a fluorimeter (F-2000, Hitachi, Tokyo, Japan). Fluorescence signal was calibrated by changing extracellular $\mathrm{K}^{+}$concentrations in the presence of $0.5-1.0 \mu \mathrm{M}$ valinomycin, which enabled us to determine the extracellular $\mathrm{K}^{+}$concentration for which there was no change in fluorescence. The membrane potential was estimated using Nernst's equation by assuming that it equals the equilibrium potential for $\mathrm{K}^{+}$in the presence of valinomycin. The cytosolic $\mathrm{K}^{+}$concentration was assumed to be $156 \mathrm{mM}$ (Jones, 1982).

\section{Feeding}

Rats were fed with plain commercial diet (SP; Funabashi Farm, Chiba, Japan) or that containing $0.023 \% \mathrm{~N}^{\mathrm{G}}$-nitro-Larginine for 3 to 20 days before the start of the experiment. Food and water were available ad libitum.

\section{Materials}

Male normotensive Wistar-Kyoto (WKY) (strain: NCrj) and spontaneously hypertensive rats (SHR) (strain: NCrj) were purchased from Charles River Japan (Kanagawa, Japan). Nifedipine, verapamil, diltiazem, cromakalim and tetrodotoxin were from Sigma Chemical Co. (St. Louis, Missouri, U.S.A.) $\mathrm{N}^{\mathrm{G}}$-nitro-L-arginine was from Aldrich Chemical Company (Milwaukee, Wisconsin, U.S.A.). Gadolinium-hydrochloride, aspirin, adenosine and phentolamine were from Wako Pure Chemical Industry (Tokyo, Japan). Cremophor EL was from Nakarai Tesque Inc. (Kyoto, Japan). Other reagents used in this work were all analytical grade.

\section{Statistics}

The values given in figures are means \pm s.e.means, unless otherwise stated, and the statistical analysis was performed by Student's $t$ test. The $n$ values indicate the number of animals.

\section{Results}

\section{Effect of extracellular $\mathrm{pH}$ change on the tension in rat} aortic strips

Effects of changes in extracellular $\mathrm{pH}\left(\mathrm{pH}_{\mathrm{o}}\right)$ on the aortic strips from WKY and SHR (11 weeks old) were first investigated (Figure 1). Decreasing $\mathrm{pH}_{\mathrm{o}}$ from 7.4 to 6.5 caused a remarkable and sustained increase in tension in the SHR aorta being nearly equal to one induced by $60 \mathrm{mM} \mathrm{KCl}$ (Figure 1a). In the case of WKY the $\mathrm{pH}_{\mathrm{o}}$ change caused a small but significant increase $(P<0.05)$ in tension (Figure $1 c)$. Increasing $\mathrm{pH}_{\mathrm{o}}$ from 7.4 to 8.0 slightly increased the tension in both cases of WKY (data not shown) and SHR (Figure 1b). These responses of aortic strips to $\mathrm{pH}$ change were reproduced at least 3 times. As shown in Figure 2, the increase in tension induced by decreasing $\mathrm{pH}_{\mathrm{o}}$ was clearly dependent on $\mathrm{pH}_{\mathrm{o}}$ in both cases of WKY and SHR. The tension increased with decreasing $\mathrm{pH}_{\mathrm{o}}$ at acidic $\mathrm{pH}_{\mathrm{o}}$ lower than 7.5, having a peak at $\mathrm{pH}_{\mathrm{o}} 6.5$ and decreased by further decreasing $\mathrm{pH}_{\mathrm{o}}$. The tension in the SHR aorta was much greater than that in the WKY aorta over the range of $\mathrm{pH}_{\mathrm{o}}$ from 5.5 to 7.0. The presence of endothelium did not affect the results described above (data not shown). 


\section{Relationship between tension and $\mathrm{pH}_{i}$}

Intracellular $\mathrm{pH}\left(\mathrm{pH}_{\mathrm{i}}\right)$ of the SHR (10 weeks old) aorta was monitored using BCECF as a fluorescent $\mathrm{pH}$ indicator. Resting $\mathrm{pH}_{\mathrm{i}}$ was $7.3 \pm 0.04(n=5)$ at $\mathrm{pH}_{\mathrm{o}}$ 7.4. Decreasing $\mathrm{pH}_{\mathrm{o}}$ from 7.4 to 6.5 caused a rapid decrease in intracellular $\mathrm{pH}$ accompanied by an elevation of tension (Figure 3a, left traces). Figure $3 \mathrm{~b}$ clearly shows the $\mathrm{pH}_{\mathrm{o}}$-dependency of $\mathrm{pH}_{\mathrm{i}}$. The ratio for the change in $\mathrm{pH}_{\mathrm{i}}$ per unit change of $\mathrm{pH}_{\mathrm{o}}$ was 0.89 .

To investigate the effect of change in $\mathrm{pH}_{\mathrm{i}}$ on contractile force more directly, $\mathrm{NH}_{4} \mathrm{Cl}$ treatment was employed. Figure 4 shows representative traces of $\mathrm{pH}_{\mathrm{i}}$ and contractile force. Resting $\mathrm{pH}_{\mathrm{i}}$ was $7.35 \pm 0.07(n=4)$. Addition of $40 \mathrm{mM} \mathrm{NH}_{4} \mathrm{Cl}$ caused an alkalinization of intracellular fluid $(7.71 \pm 0.12$, $n=4$ ) accompanied by a faint increase in the tension. Removal of $\mathrm{NH}_{4} \mathrm{Cl}$ resulted in a transient decrease in $\mathrm{pH}_{\mathrm{i}}(6.95 \pm 0.10$, $n=4$ ) attended by a marked increase in the tension. DIDS, a representative blocker of $\mathrm{Cl}^{-} / \mathrm{HCO}_{3}{ }^{-}$exchanger, inhibited both the decrease in $\mathrm{pH}_{\mathrm{i}}$ and APIC induced not only by decreasing $\mathrm{pH}_{\mathrm{o}}$ but also by the $\mathrm{NH}_{4} \mathrm{Cl}$-washout acidification (data not shown).

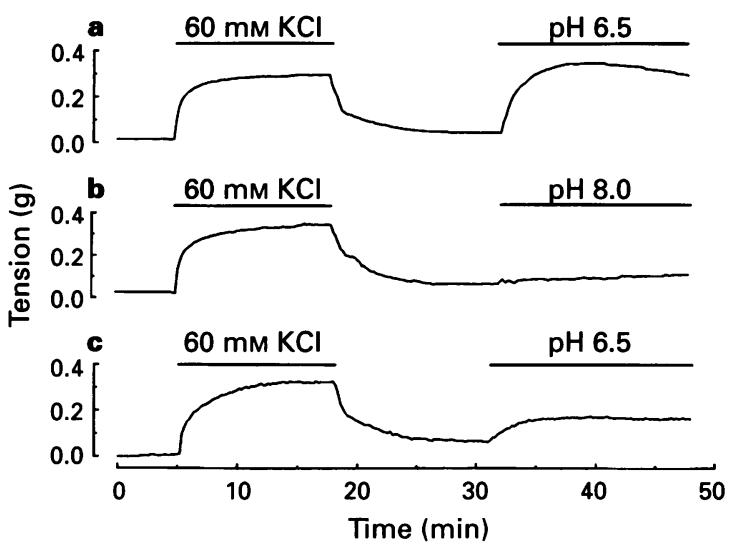

Figure 1 Typical recordings of the contractile effects of changing $\mathrm{pH}_{\mathrm{o}}$ on resting strips of aorta. Spiral strips of thoracic aortae from 11 -week-old SHR $(a, b)$ and WKY (c) were precontracted 3 times by adding $60 \mathrm{mM} \mathrm{KCl}$ and then $\mathrm{pH}_{\mathrm{o}}$ was changed. Three traces show the last trial of $\mathrm{KCl}(60 \mathrm{mM})$ and following $\mathrm{pH}_{\mathrm{o}}$ change. External $\mathrm{pH}$ was changed from 7.4 to 6.5 (a and c) or $8.0(\mathrm{~b})$.

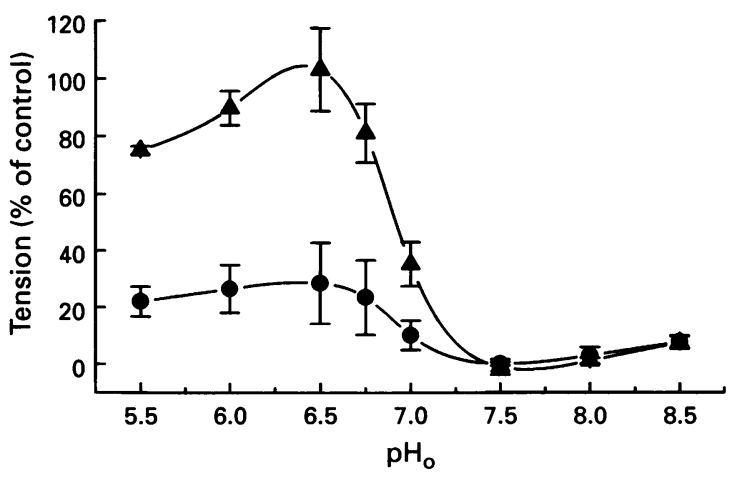

Figure 2 The relation between $\mathrm{pH}_{\mathrm{o}}$ and contraction evoked by changing $\mathrm{pH}_{\mathrm{o}}$. Spiral strips of thoracic aortae from 11-week-old WKY (O) and SHR (A) were precontracted 3 times by adding $60 \mathrm{mM} \mathrm{KCl}$ and then the contractions evoked by changing $\mathrm{pH}_{\mathrm{o}}$ from 7.4 to various $\mathrm{pH}(5.5$ to 8.0$)$ were observed. The contractile response to the last trial of $60 \mathrm{mM} \mathrm{KCl}$ at $\mathrm{pH} 7.4$ is expressed as $100 \% . n=4-$ 10.

\section{Effects of several drugs on APIC}

Effects of several drugs on the APIC (pH 6.5) in SHR (11 weeks old) were investigated (Figure 5). Verapamil (1 $\mu \mathrm{M})$, a representative blocker of voltage-sensitive $\mathrm{Ca}^{2+}$ channels and adenosine decreased APIC by approximately $90 \%$. However, tetrodotoxin $(10 \mu \mathrm{M})$, a potent $\mathrm{Na}^{+}$channel blocker, $\mathrm{Gd}^{3+}$ $(100 \mu \mathrm{M})$, a blocker of stretch-activated cation channels, phentolamine $(10 \mu \mathrm{M})$, an $\alpha$-adrenoceptor antagonist and aspirin (1 mM), a cyclo-oxygenase inhibitor failed to inhibit

a

$\mathrm{pH} 6.5$

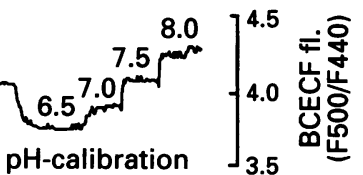

$0.1 \mathrm{~g} \mid \int_{\frac{600 \mathrm{~s}}{u}}$

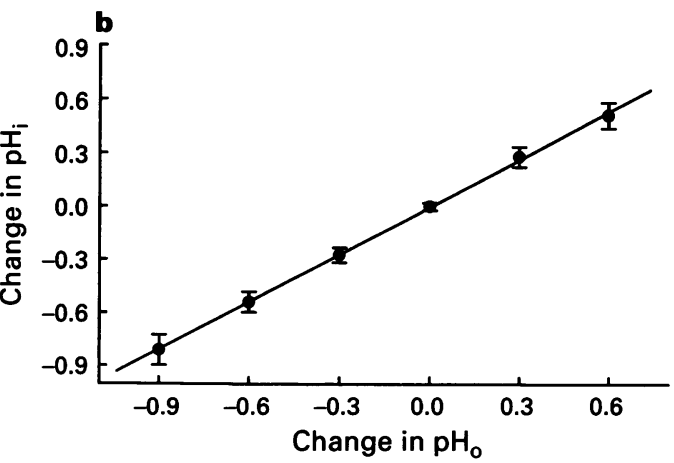

Figure 3 Intracellular $\mathrm{pH}$ change and contraction of aortic strips from SHR induced by acidic $\mathrm{pH}_{\mathrm{o}}$. Aortic strips from SHR (10 weeks old) were loaded with BCECF and then simultaneous measurements of intracellular $\mathrm{pH}$ and contraction were carried out. After precontraction with $60 \mathrm{mM} \mathrm{KCl}$, the strips were contracted by changing $\mathrm{pH}_{\mathrm{o}}$ from 7.4 to 6.5 ; then intracellular $\mathrm{pH}$ was calibrated by nigericin-high $\mathrm{KCl}$ method as described under Methods. (a) Representative traces of $\mathrm{pH}_{\mathrm{i}}$ and contraction. Four preparations from different animals were used. (b) The relation between the change in $\mathrm{pH}_{0}$ and the subsequent change in $\mathrm{pH}_{\mathrm{i}}(n=6)$. The regression line fitted has a correlation coefficient of 0.99 and a slope of $0.89 \pm 0.01$.

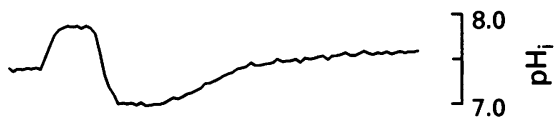

$40 \mathrm{mM} \mathrm{NH}_{4} \mathrm{Cl}$

$0.1 \mathrm{~g}$

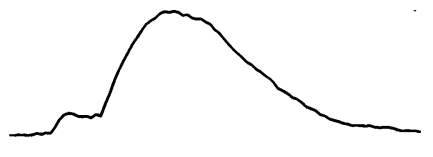

Figure 4 Effects of addition and washout of ammonium chloride on $\mathrm{pH}_{\mathrm{i}}$. Aortic strips from SHR (11 weeks old) were loaded with BCECF and then simultaneous measurements of intracellular pH (upper trace) and contraction (lower trace) were carried out. After precontraction with $60 \mathrm{mM} \mathrm{KCl}$, the strip was incubated with $40 \mathrm{mM}$ $\mathrm{NH}_{4} \mathrm{Cl}$ for 1 min and then $\mathrm{NH}_{4} \mathrm{Cl}$ was removed by washing with fresh buffer. Four preparations from different animals were used. 
APIC. Contraction evoked by $\mathrm{NH}_{4} \mathrm{Cl}$-induced acidification showed the same responses to these drugs (data not shown). These results suggest that APIC is caused by membrane depolarization of the aorta. Therefore, the effect of cromakalim, a potent activator of $\mathrm{K}^{+}$channels was investigated to clarify the involvement of depolarization in the mechanism of APIC (Figure 6). Cromakalim inhibited APIC as well as $\mathrm{KCl}$-induced contraction in a concentration-dependent manner with $\mathrm{IC}_{50}$ values of 0.23 and $0.50 \mu \mathrm{M}$, respectively.

\section{Effects of acidic $\mathrm{pH}_{o}$ on $\left[\mathrm{Ca}^{2+}\right]_{i}$}

Contraction of vascular smooth muscle is regulated by several factors including $\left[\mathrm{Ca}^{2+}\right]_{i} .\left[\mathrm{Ca}^{2+}\right]_{i}$ in the SHR (10 weeks old) aorta was monitored by use of fura-2 as a fluorescent $\mathbf{C a}^{2+}$ indicator. As shown in Figure 7a, acidic $\mathrm{pH}_{\mathrm{o}}(\mathrm{pH}$ 6.5) induced a rapid and sustained increase in $\left[\mathrm{Ca}^{2+}\right]_{\mathrm{i}}$ followed by the contraction. Returning to normal $\mathrm{pH}$ (7.4) abolished APIC. The application of EGTA $(2 \mathrm{mM})$ to reduce extracellular $\mathrm{Ca}^{2+}$ below $1 \mu \mathrm{M}$ eliminated both the $\mathrm{Ca}^{2+}$ mobilization and APIC.

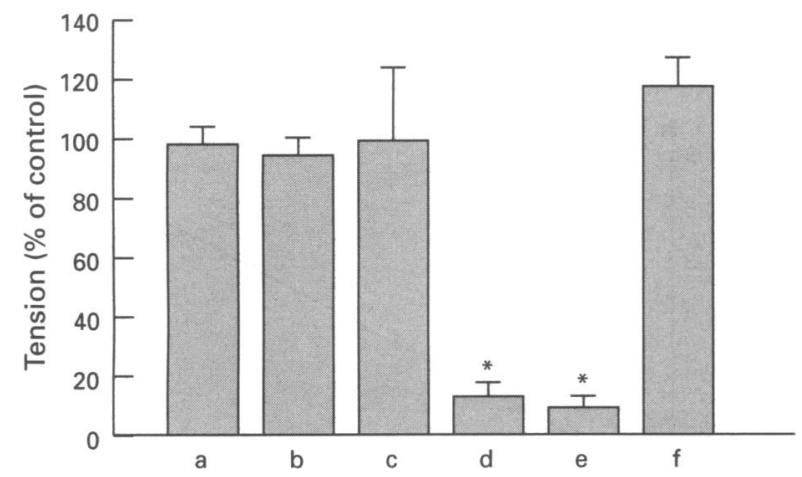

Figure 5 Effects of several drugs on contraction response of SHR aortae to acidic $\mathrm{pH}_{\mathrm{o}}$. Aortic strips from SHR (11 weeks old) were contracted by changing $\mathrm{pH}_{\mathrm{o}}$ from 7.4 to 6.5. After reaching a plateau, several drugs were added. Tension was expressed as percentage of control value obtained in the absence of each drug $(n=5)$. (a) Phentolamine $10 \mu \mathrm{M}$; (b) tetrodotoxin $10 \mu \mathrm{M}$; (c) $\mathrm{Gd}^{3+}$ $100 \mu \mathrm{M}$; (d) verapamil $1 \mu \mathrm{M}$; (e) adenosine $1 \mathrm{mM}$; (f) aspirin $1 \mathrm{mM}$. *Significantly different from control $(P<0.01)$.

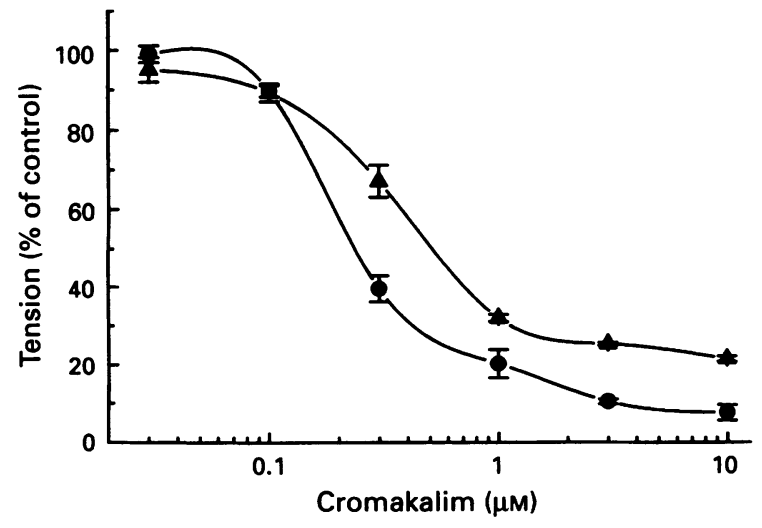

Figure 6 Effects of cromakalim on $\mathrm{KCl}$ - and acidic $\mathrm{pH}_{\mathrm{o}}$-induced contraction of aortic strips from SHR. Aortic strips from SHR (10 weeks old) were precontracted 3 times by adding $60 \mathrm{mM} \mathrm{KCl}$. Then, the strips were contracted by changing $\mathrm{pH}_{\mathrm{o}}$ from 7.4 to $6.5(0)$ - or adding $30 \mathrm{~mm} \mathrm{KCl}(\Delta)$. Cromakalim was added cumulatively. Tension was expressed as percentage of control value obtained without cromakalim $(n=4)$.
The $\mathrm{Ca}^{2+}$ transient as well as APIC was also abolished by adding verapamil $(1 \mu \mathrm{M}), \mathrm{a} \mathrm{Ca}^{2+}$ channel blocker (Figure $7 \mathrm{~b}$ ). Adenosine caused a concentration-dependent inhibition of APIC with an $\mathrm{IC}_{50}$ value of $0.475 \mathrm{mM}$. As shown in Figure 8a, $1 \mathrm{mM}$ adenosine markedly inhibited not only the contraction but also an increase in cytosolic $\mathrm{Ca}^{2+}$ concentrations evoked by changing $\mathrm{pH}_{\mathrm{o}}$ to 6.5 . Furthermore, pretreatment of the strip with $1 \mathrm{mM}$ adenosine abolished both the APIC and $\mathrm{Ca}^{2+}$ transient without affecting $\mathrm{pH}_{\mathrm{i}}$ (Figure $8 \mathrm{~b}$ ). Similar effects of these drugs were also observed in WKY (data not shown).

\section{Effects of acidic $\mathrm{pH}_{\mathrm{o}}$ on membrane potential of vascular} smooth muscle cells

To assess the effect of acidic $\mathrm{pH}_{\mathrm{o}}$ on membrane potential, primary cultures of vascular smooth muscle cells were prepared from SHR aorta by enzymatic dispersion and their membrane potential was measured by a potential-indicator dye diS- $\mathrm{C}_{3}(5)$ (Figure 9). The value of the resting membrane potential at normal $\mathrm{pH}_{\mathrm{o}}$ was $-52 \pm 5 \mathrm{mV}(n=3)$. Addition of $60 \mathrm{mM} \mathrm{KCl}$ as a positive control induced a depolarization to $-15.1 \pm 4 \mathrm{mV}(n=3)$. Acidic $\mathrm{pH}_{\mathrm{o}}(\mathrm{pH} 6.5)$ remarkably decreased membrane potential to $-26.7 \pm 7 \mathrm{mV}(n=3)$ which was close to that obtained by adding $30 \mathrm{mM} \mathrm{KCl}$ $(-23.8 \pm 5 \mathrm{mV}, n=3)$. Cromakalim markedly inhibited both $\mathrm{KCl}$ - and acidic $\mathrm{pH}_{\mathrm{o}}$-induced depolarization (data not shown).

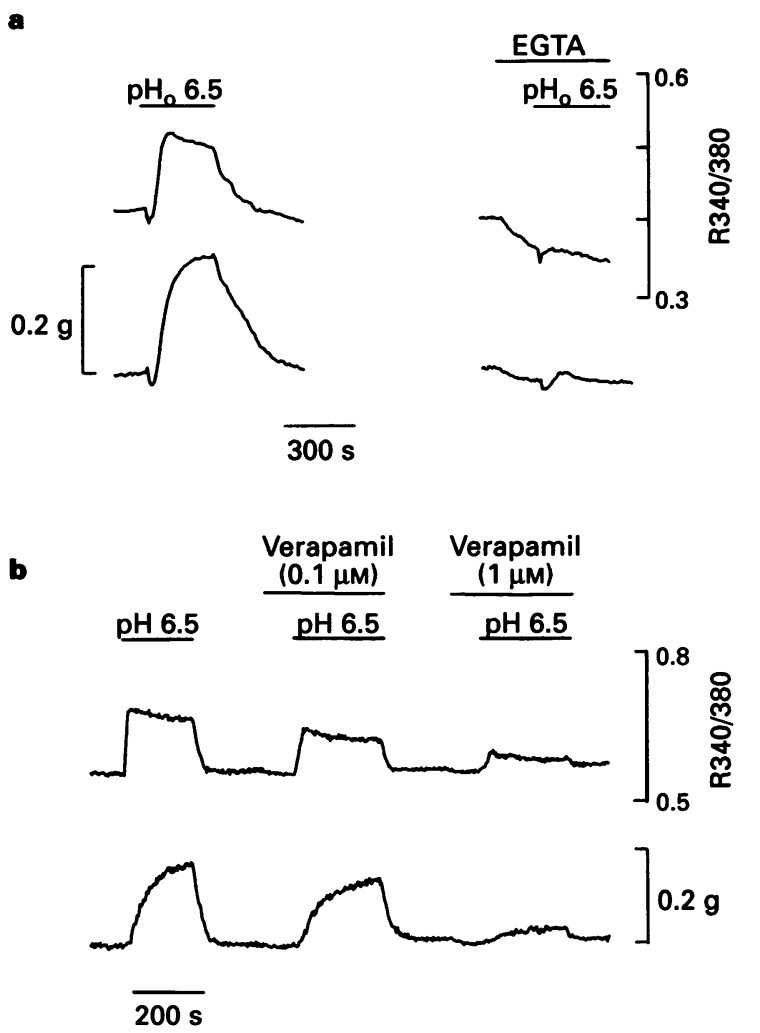

Figure 7 Acidic $\mathrm{pH}_{\mathrm{o}}$-induced contraction and elevation of cytosolic $\mathrm{Ca}^{2+}$ level of the rat aorta from SHR. Aortic strips from SHR (10 weeks old) were loaded with fura-2 and then simultaneous measurements of $\left[\mathrm{Ca}^{2+}\right]_{i}$ and contraction were carried out. Upper traces show the ratio of intensity of the fluorescence induced by excitation at $340 \mathrm{~nm}$ to that at $380 \mathrm{~nm}$ as an index of relative cytosolic $\mathrm{Ca}^{2+}$ level. Lower traces show the contraction corresponds to the upper trace. Four preparations from different animals were used. (a). Left traces show contraction and $\mathrm{Ca}^{2+}$ mobilization evoked by decreasing $\mathrm{pH}_{\mathrm{o}}$ from 7.4 to 6.5 . Right traces show effects of $2 \mathrm{mM}$ EGTA on APIC and intracellular $\mathrm{Ca}^{2+}$ mobilization. (b) Effects of verapamil $(0.1$ and $1.0 \mu \mathrm{M})$ on APIC and $\left[\mathrm{Ca}^{2+}\right]_{\mathrm{i}}$. 
a

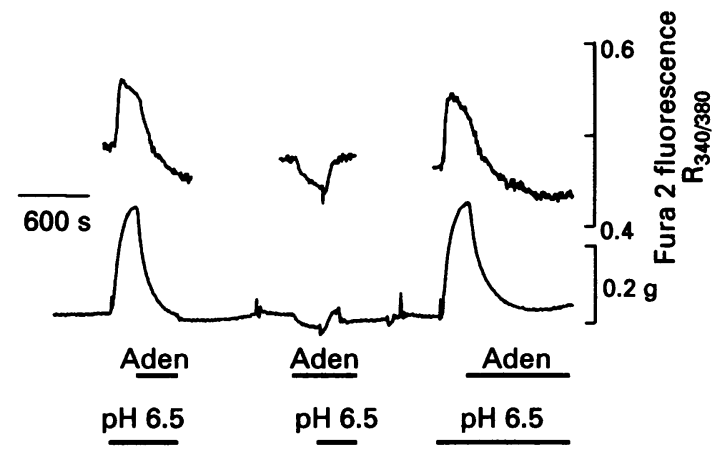

b
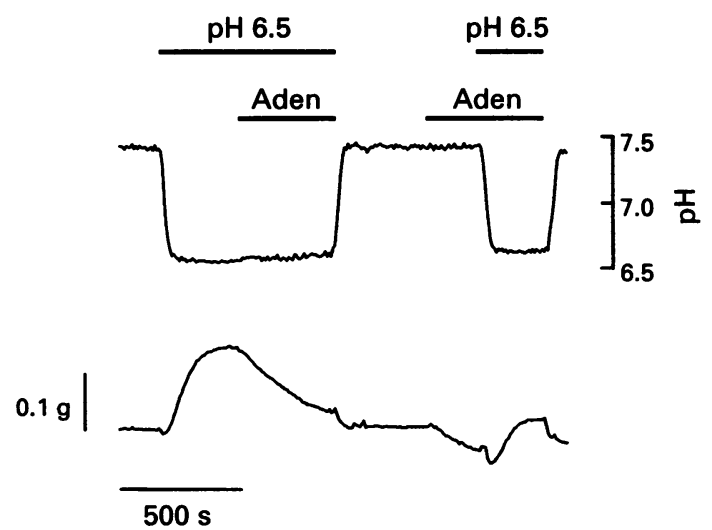

Figure 8 Effects of adenosine (Aden) on acidic $\mathrm{pH}_{\mathrm{o}}$-induced contraction, $\left[\mathrm{Ca}^{2+}\right]_{\mathrm{i}}$ and $\mathrm{pH}_{\mathrm{i}}$ in aortic strip from SHR. Aortic strips from SHR (11 weeks old) were loaded with fura-2 (a) or BCECF (b) and then simultaneous measurements of $\left[\mathrm{Ca}^{2+}\right]$ or $\mathrm{pH}_{\mathrm{i}}$ and contraction were carried out. Aortic strips were contracted by changing $\mathrm{pH}_{\mathrm{o}}$ from 7.4 to 6.5 . Typical recording of the vasodilator effect of adenosine is shown (three different animals were used). One mM adenosine (Aden) was applied after the contraction reached a plateau. When the contraction returned to around the resting level after changing $\mathrm{pH}_{\mathrm{o}}$ to $7.4,1 \mathrm{mM}$ adenosine was applied and then $\mathrm{pH}_{\mathrm{o}}$ was changed to 6.5. Application of adenosine at $\mathrm{pH} 6.5$ was repeated again in (a). Upper traces are $\left[\mathrm{Ca}^{2+}\right]_{i}(\mathrm{a})$ or $\mathrm{pH}_{\mathrm{i}}(\mathrm{b})$ and the lower traces are contraction ( $a$ and $b)$.

\section{Relationship between acidic $\mathrm{pH}_{\mathrm{o}}$-induced contraction and blood pressure}

The results described above suggest that the contractile response to acidic $\mathrm{pH}_{\mathrm{o}}$ is strengthened by the elevation of blood pressure. Therefore, mean blood pressure of WKY and SHR at various ages and APIC in their aortae were examined. As shown in Figure 10a, the mean blood pressure of WKY at 5 weeks old was $114 \pm 4.5 \mathrm{mmHg}$. It increased gradually with increase in age $(7 \%$ increase after 9 weeks from 5 to 14 weeks old). On the other hand, blood pressure of SHR at 5 weeks old was already much greater than that of WKY at the same age $(131 \pm 2.1 \mathrm{mmHg}$ for SHR). It increased markedly with increasing age (50\% increase after 10 weeks from 5 to 15 weeks old). As shown in Figure 10b, APIC (pH 6.5) was also agedependent. APIC in the SHR aorta increased two times after 10 weeks from 5 to 15 weeks old. In the case of WKY it also increased with increase in age but the increase was small compared to SHR. Figure 10c indicates that there is a close correlation between the increase in APIC and the elevation of blood pressure $(r=0.90)$.

\section{Effect of feeding with $N^{G}$-nitro-L-arginine on blood pressure and $A P I C$ in $W K Y$}

Ikeda et al. (1992) reported that feeding with $\mathrm{N}^{\mathrm{G}}$-nitro-L-arginine elevated the blood pressure of WKY. APIC was ex-

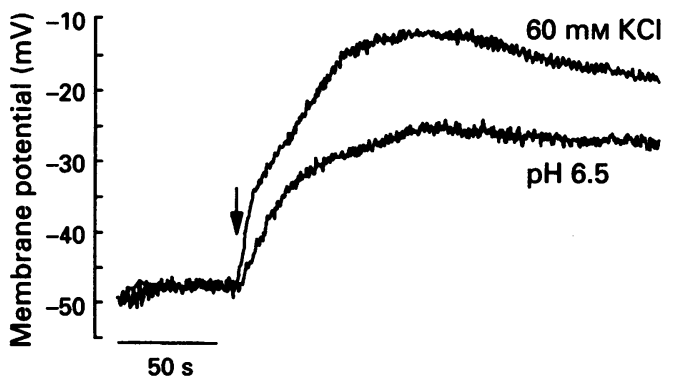

Figure 9 Effect of acidic $\mathrm{pH}_{\mathrm{o}}$ on the membrane potential of vascular smooth muscle cells from SHR aortae. Cultured smooth muscle cells attached to glass coverslips were prewarmed at $37^{\circ} \mathrm{C}$ for $5 \mathrm{~min}$ and then incubated with $0.5 \mu \mathrm{M}$ diS- $C_{3}(5)$ before assaying fluorescence. Measurements were carried out with excitation at $620 \mathrm{~nm}$ and emission at $680 \mathrm{~nm}$, respectively. After the fluorescence intensity stabilized, $\mathrm{HCl}$ to change $\mathrm{pH}_{\mathrm{o}}$ from 7.4 to 6.5 or $60 \mathrm{mM} \mathrm{KCl}$ was added. Representative traces are shown $(n=3)$.

amined in the aorta from WKY fed with $0.023 \% \mathrm{~N}^{\mathrm{G}}$-nitro-Larginine. Feeding with $\mathrm{N}^{\mathrm{G}}$-nitro-L-arginine elevated the blood pressure of WKY (14 weeks old) from $121 \pm 8.1$ to $132 \pm 0.49 \mathrm{mmHg}$ after 2 days and to $153 \pm 8.5 \mathrm{mmHg}$ after 9 days (Figure 11a). In these rat aortae APIC (pH 6.5) markedly increased from $34.6 \pm 11.3 \%$ to $71.6 \pm 9.2 \%$ after 2 days and to $96.1 \pm 17.7 \%$ after 9 days in parallel to the blood pressure. Both the increase in blood pressure and the enhancement of APIC by prolonged oral administration of $\mathrm{N}^{\mathrm{G}}$-nitro-L-arginine disappeared 10 days after stopping the feeding. As shown in Figure $11 \mathrm{~b}$, there is a close correlation between the increase in APIC and the elevation of blood pressure $(r=0.95)$. In vitro treatment of aortae with $\mathrm{N}^{\mathrm{G}}$-nitro-L-arginine did not cause any change in APIC.

\section{Discussion}

Decreasing $\mathrm{pH}_{\mathrm{o}}$ caused a rapid and sustained decrease in $\mathrm{pH}_{\mathrm{i}}$ followed by a contraction in rat aorta. Acidic $\mathrm{pH}_{\mathrm{o}}$-induced contraction (APIC) was not affected by an $\alpha$-adrenoceptor blocker (phentolamine), a cyclo-oxygenase inhibitor (aspirin) and a $\mathrm{Na}^{+}$channel blocker (tetrodotoxin). The aortic strips used in the present experiments were without endothelium. These results would eliminate the possible involvement of an indirect action through the release of chemical mediators as the mechanism of action of acidic $\mathrm{pH}_{\mathrm{o}}$, suggesting the direct action of acidic $\mathrm{pH}_{\mathrm{o}}$. There was a linear relationship between the $\mathrm{pH}_{\mathrm{o}}$ and steady-state $\mathrm{pH}_{\mathrm{i}}$ over the $\mathrm{pH}_{\mathrm{o}}$ range examined. There may be a rapid passage of $\mathrm{H}^{+}$across the plasma membrane of aortic cells. $\mathrm{H}^{+}$entry through $\mathrm{Na}^{+} / \mathrm{H}^{+}$exchanger is thermodynamically unlikely, because the $\mathrm{pH}_{\mathrm{o}}$ lower than 6.0 would be required for this mechanism under the normal condition of intracellular $\mathrm{Na}$ concentrations and $\mathrm{pH}_{\mathrm{i}}$. A possible mechanism is $\mathrm{H}^{+}$entry through $\mathrm{Cl}^{-} / \mathrm{HCO}_{3}{ }^{-}$exchanger. This mechanism is supported by the observation that DIDS, a representative blocker of $\mathrm{Cl}^{-} / \mathrm{HCO}_{3}{ }^{-}$exchanger, inhibited both the decreases in $\mathrm{pH}_{\mathrm{i}}$ and APIC. Furthermore, the contraction was also induced by the decrease in $\mathrm{pH}_{\mathrm{i}}$ by the removal of $\mathrm{NH}_{4} \mathrm{Cl}$. These results suggest that APIC is mainly caused by the decrease in $\mathrm{pH}_{\mathrm{i}}$. However, a small decrease in $\mathrm{pH}_{\mathrm{i}}$ induced by the removal of $\mathrm{NH}_{4} \mathrm{Cl}$ caused a large increase in tension compared with the acidic $\mathrm{pH}_{\mathrm{o}}$-induced decrease in $\mathrm{pH}_{\mathrm{i}}$. The addition of $\mathrm{NH}_{4} \mathrm{Cl}$ did not cause any remarkable $\mathrm{pH}_{\mathrm{o}}$ change. Therefore, it remains uncertain which the real trigger of the concentration is - absolute $\mathrm{pH}_{\mathrm{i}}$ or $\Delta \mathrm{pH}$ (the difference between $\mathrm{pH}_{\mathrm{i}}$ and $\mathrm{pH}_{\mathrm{o}}$ ).

It has been indicated that contractions of rat mesentery and porcine coronary are associated with intracellular alkalinization (Austin \& Wray, 1993; Nagesetty \& Paul, 1995). We also confirmed their observation. However, in this study, contrac- 

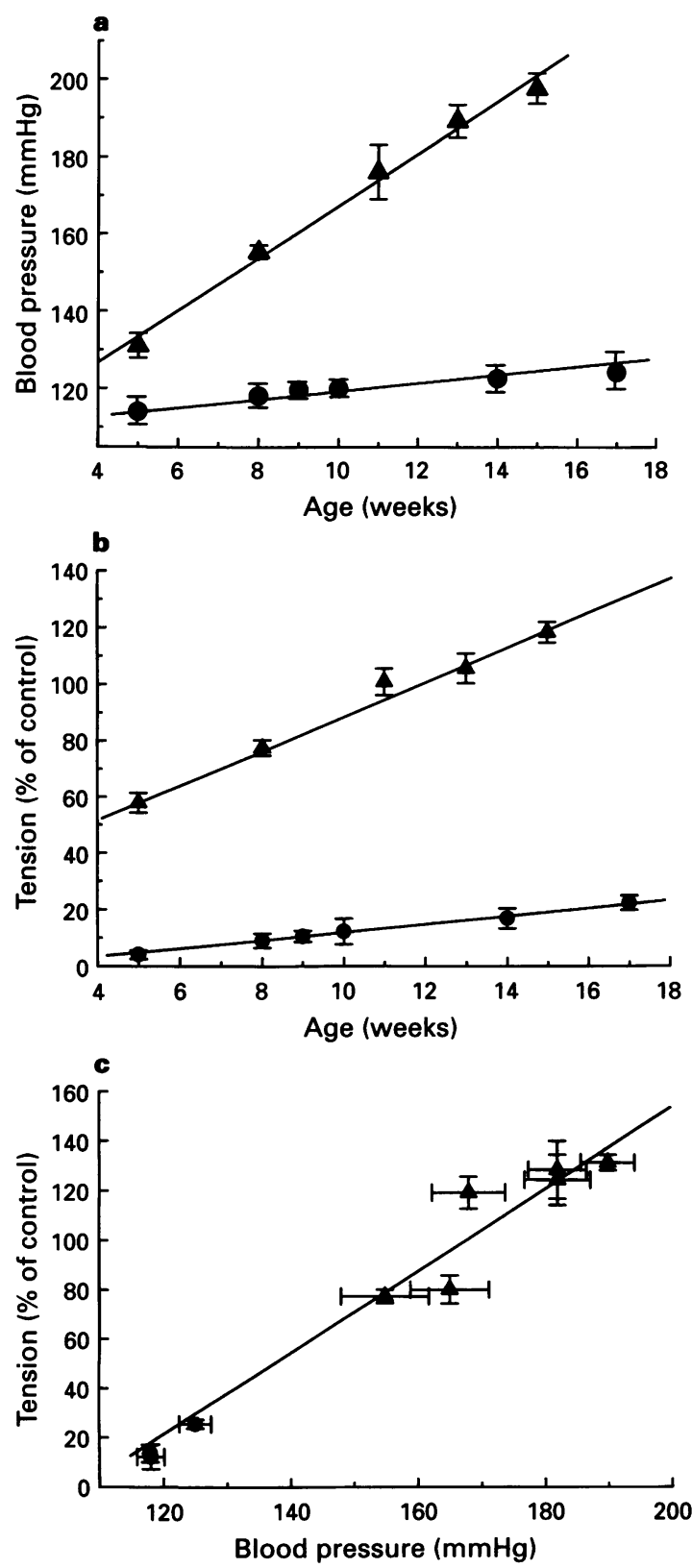

Figure 10 Relationships among age, blood pressure and acidic $\mathrm{pH}_{\mathrm{o}}-$ induced contraction of SHR and WKY. (a) Development of blood pressure by aging; (b) development of acidic $\mathrm{pH}_{\mathrm{o}}$-induced contraction by aging. Tension induced by changing $\mathrm{pH}_{\mathrm{o}}$ from 7.4 to 6.5 is expressed as percentage of contraction induced by $60 \mathrm{mM} \mathrm{KCl}$ at pH 7.4; (c) relationship between the blood pressure and the contractions. (O) WKY; (A) SHR. The regression line fitted has a correlation coefficient of 0.90 and a slope of $1.65 \pm 0.43(n=4-6)$.

tion of rat aorta is associated with intracellular acidification. Rabbit aorta shows almost the same contractile response to acidic $\mathrm{pH}$ (our unpublished observation). Battle et al. (1993) showed that intracellular acidification increases $\mathrm{Ca}^{2+}$ from an intracellular store(s) in rat aortic vascular smooth muscle cells. Blood vessels from distinct vascular regions may display different sensitivities to changes in extracellular $\mathrm{pH}$.

APIC was abolished by elimination of extracellular $\mathrm{Ca}^{2+}$ or treatment with verapamil, a potent inhibitor of voltage-dependent $\mathrm{Ca}^{2+}$ channels. Increase in $\left[\mathrm{Ca}^{2+}\right]_{i}$ induced by acidic $\mathrm{pH}_{\mathrm{o}}$ was suppressed by the application of verapamil or $\mathrm{Ca}^{2+}$. free medium. These results suggest that APIC is triggered by $\mathrm{Ca}^{2+}$ influx through voltage-dependent $\mathrm{Ca}^{2+}$ channels. Voltage-dependent $\mathrm{Ca}^{2+}$ channels are activated by the depolar-
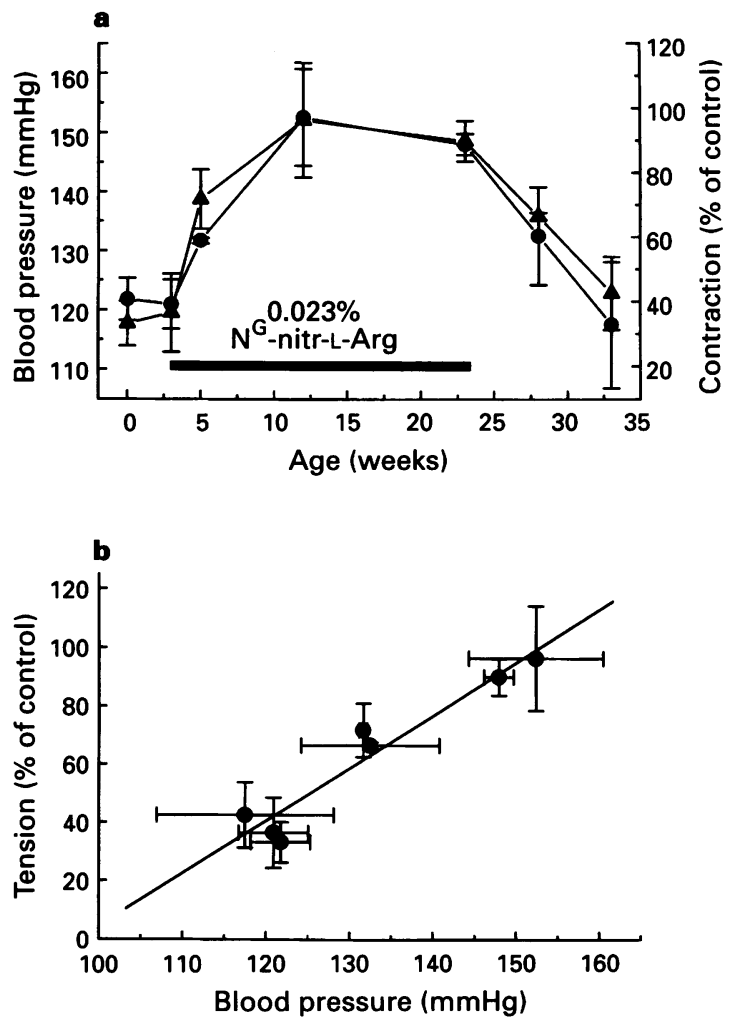

Figure 11 Effects of feeding with $\mathrm{N}^{\mathrm{G}}$-nitro-L-arginine on blood pressure and acidic- $\mathrm{pH}_{\mathrm{o}}$-induced contraction in WKY. WKY (14 week old) were fed with $0.023 \% \mathrm{~N}^{\mathrm{G}}$-nitro-L-arginine for 20 days. (a) Increase in blood pressure $(0)$ and enhancement of acidic $\mathrm{pH}_{\mathrm{o}^{-}}$ induced contraction $(\boldsymbol{A})$ by feeding with $\mathrm{N}^{\mathrm{G}}$-nitro-L-arginine. Contraction induced by changing $\mathrm{pH}_{\mathrm{o}}$ from 7.4 to 6.5 is expressed as percentage of that induced by $60 \mathrm{mM} \mathrm{KCl}$ at $\mathrm{pH} 7.4$. (b) Relationship between blood pressure and contraction. The regression line fitted has a correlation coefficient of 0.96 and a slope of $1.79 \pm 0.24(n=5)$.

ization of the plasma membrane. It has been reported that cromakalim activates $\mathrm{K}^{+}$channels to hyperpolarize the plasma membrane resulting in relaxation of smooth muscle (Yanagisawa et al., 1990). To confirm the participation of depolarization in the mechanism of APIC, the effect of cromakalim on APIC was investigated. APIC was diminished by cromakalim in a concentration-dependent manner with an IC $_{50}$ value similar to that in concentrations induced by $30 \mathrm{mM}$ $\mathrm{KCl}$. Furthermore, acidic $\mathrm{pH}_{\mathrm{o}}$ induced depolarization of primary cultured smooth muscle cells from SHR aorta. Cromakalim markedly inhibited both $\mathrm{KCl}$ - and acidic $\mathrm{pH}_{\mathrm{o}}$ induced depolarization. These results suggest that acidic $\mathrm{pH}_{\mathrm{o}}$ depolarizes the plasma membrane of smooth muscle cells and then voltage-dependent $\mathrm{Ca}^{2+}$ channels are activated to cause APIC. However, APIC at pH 6.5 was much larger than that caused by $30 \mathrm{mM} \mathrm{KCl}$, although the depolarization induced by acidic $\mathrm{pH}_{\mathrm{o}}(6.5)$ was close to that obtained by adding $30 \mathrm{mM}$ $\mathrm{KCl}$. Therefore, another mechanism contributing to APIC may also be present.

It is well known that the membrane potential of smooth muscle cells is determined by the permeability of $\mathrm{K}^{+}$as well as $\mathrm{Ca}^{+}$and both $\mathrm{K}^{+}$and $\mathrm{Ca}^{2+}$ channels are inhibited by acidic $\mathrm{pH}_{\mathrm{i}}$ (Harder, 1982). Acidic $\mathrm{pH}_{\mathrm{o}}$ cannot directly activate voltage-dependent $\mathrm{Ca}^{2+}$ channels, indicating that $\mathrm{Ca}^{2+}$ channels are not the first determinant of the resting membrane potential of the aorta in acidic $\mathrm{pH}_{\mathrm{o}}$. Therefore it is probable that inhibition of $\mathrm{K}^{+}$channels is responsible for depolarization in the rat aorta induced by acidification of extracellular fluid. Various types of $\mathrm{K}^{+}$channels in smooth muscle cells have been extensively studied by numerous investigators (Bolton \& 
Beech, 1992). The $\mathrm{pH}$-sensitive $\mathrm{K}^{+}$channel is sensitive to $\mathrm{pH}_{\mathrm{i}}$ and has a $K_{\mathrm{d}}$ value of 7.28 similar to the resting $\mathrm{pH}_{\mathrm{i}}$ (Suzuki $e t$ al., 1994). Acidic $\mathrm{pH}_{\mathrm{o}}$ caused a rapid decrease in $\mathrm{pH}_{\mathrm{i}}$ of the rat aorta. Furthermore, DIDS, an inhibitor of $\mathrm{Cl}^{-} / \mathrm{HCO}_{3}^{-}$exchanger partially inhibited APIC, suggesting that APIC is at least partly caused by $\mathrm{H}^{+}$entry through the mechanism. It is likely that intracellular $\mathrm{H}^{+}$reduces the open probability of $\mathrm{K}^{+}$ channels of the aortic smooth muscle or competes with $\mathrm{K}^{+}$for the cation efflux pathway to cause membrane depolarization. It has been reported that $\mathrm{Ca}^{2+}$-activated $\mathrm{K}^{+}$channels are highly activated in the resting state of arteries from SHR (Asano $e t$ al., 1993; England et al., 1993). An attractive explanation is that the $\mathrm{K}^{+}$channel that determines the membrane potential of aortic smooth muscle cells is enhanced in SHR to provide a counter-regulatory mechanism to limit arterial smooth muscle excitability. However, the alteration may easily cause APIC in acidosis.

The responsiveness to acidic $\mathrm{pH}$ was more evident in SHR than in WKY over the range of $\mathrm{pH}_{\mathrm{o}}$ from 5.5 to 7.5. Both APIC and blood pressure markedly increased with increasing age of SHR, but in WKY both the parameters increased gradually. Prolonged oral administration of $\mathrm{N}^{\mathrm{G}}$-nitro-L-arginine in WKY caused a remarkable increase in APIC in parallel to the elevation of blood pressure. The increase in both parameters disappeared after stopping the administration of $\mathrm{N}^{\mathrm{G}}$ nitro-L-arginine. Interestingly, there was a close relationship between the elevation of blood pressure and the increase in APIC in all cases. Furthermore, acute hypertension augments the contractile response of the vascular smooth muscle (Sofola et al., 1993; Griffith et al., 1994). These results suggest that the increase in APIC is due to the elevation of blood pressure but not to hereditary factors. It is also suggested that acidosis becomes a crucial risk factor and may cause spasm of blood vessels in hypertension.

Mechanical stress often modulates characteristics of circulation systems (Kulik \& Alvarado, 1993; Schwartzkopf et al., 1993; Shida \& Isoyama, 1993; Sterpetti et al., 1993). Some functional change that continues after dissection may occur in smooth muscle cells in vessel walls under mechanical stress, i.e. stretching the smooth muscle cells or some hormonal stimulation during exposure to high blood pressure. Stretch-activated cation channels have been found in various types of cells including vascular endothelial and smooth muscle cells and may play important roles in regulating the vascular tone (Naruse \& Sokabe, 1993; Kirber et al., 1988; Hisada et al., 1993). It is likely that these channels become sensitive to acidic pH due to high blood pressure. However, APIC was not inhibited by $\mathrm{Gd}^{3+}$, a specific blocker of the channels (Yang \& Sachs, 1989; Naruse \& Sokabe, 1993). Therefore, stretch-activated cation channels may not contribute to the mechanism by which high blood pressure accelerates APIC.

Adenosine is an important metabolite associated not only with cellular metabolism but also with vasodilatation (Collis \& Hourani, 1993; Ngai \& Winn, 1993). Furthermore, several lines of evidence suggest that ischaemia often causes acidosis that may affect various functions of vascular smooth muscle and that adenosine is an endogenous protective agent in ischaemia (Berne et al., 1974; Rudolphi et al., 1993; Laxson et al., 1993). The detailed protective mechanism of adenosine is as yet unresolved; the most likely hypothesis is that reduction in the intracellular cyclic AMP level by binding of adenosine to $\mathrm{A}_{1}$ receptors results in decreasing $\mathrm{Ca}^{2+}$ influx (Rudolphi et al., 1993). Adenosine caused a concentration-dependent inhibition of APIC and intracellular $\mathrm{Ca}^{2+}$ transient. Our results suggest that acidosis stimulates the activity of voltage-dependent $\mathrm{Ca}^{2+}$ channels through depolarization of the plasma membrane of smooth muscle. It is probable that adenosine decreases intracellular cyclic AMP concentrations and then inhibits $\mathrm{Ca}^{2+}$ influx to cause vasodilatation. This is consistent with the accepted role of adenosine in ischaemia.

In summary, APIC in the rat aorta is increased by the elevation of blood pressure. The contraction may be caused by $\mathrm{Ca}^{2+}$ influx through voltage-sensitive $\mathrm{Ca}^{2+}$ channels mainly due to acidic $\mathrm{pH}_{\mathrm{o}}$-induced depolarization of the plasma membrane of smooth muscle cells.

We thank Dr Norimichi Nakahata of our department for helpful discussions and his critical advice on the experiments described in this paper. This work was supported in part by a Grant-in-Aid for Scientific Research from the Ministry of Education, Science and Culture of Japan (No. 05557103). We are grateful to The Mitsubishi Foundation and the Nishinomiya Foundation for Basic Medical Research for supplying grants.

\section{References}

AUSTIN, C. \& WRAY, S. (1993). Extracellular pH signals affect rat vascular tone by rapid transduction into intracellular $\mathrm{pH}$ changes. J. Physiol., 466, 1-8.

ASANO, M., MASUZAWA-ITO, K. \& MATSUDA, T. (1993). Charybdotoxin-sensitive $\mathrm{K}^{+}$channels regulate the myogenic tone in the resting state of arteries from spontaneously hypertensive rats. Br. J. Pharmacol., 108, 214-222.

BATRA, V.K., MCNEILL, J.R., XU, Y., WILSON, T.W \& GOPALAKRISHNAN, V. (1993). ET B $_{B}$ receptors on aortic smooth muscle cells of spontaneously hypertensive rats. Am. J. Physiol., 264, C479C484.

BATTLE, D.C., PECES, R., LAPOINTE, M.S., YE, M. \& DAUGIRDAS, J.T. (1993). Cytosolic free calcium regulation in response to acute changes in intracellular $\mathrm{pH}$ in vascular smooth muscle. Am. J. Physiol., 264, C932-C943.

BERNE, R.M., RUBIO, R. \& CURNISH, R.R. (1974). Release of adenosine from ischemic brain: effect on cerebral vascular resistance and incorporation into cerebral adenine nucleotides. Circ. Res., 35, 262-271.

BOLTON, T.B. \& BEECH, D.J. (1992). Smooth muscle potassium channels: their electrophysiology and function in Potassium Channel Modulators. ed. Weston, A.H. \& Hamilton, T.C., pp. $144-180$. Oxford: Blackwell.

BUTWELL, N.A., RAMASAMY, R., LAZAR, I., SHERRY, A.D. \& MALLOY, C.R. (1993). Effect of lidocaine on contracture, intracellular sodium, and $\mathrm{pH}$ in ischemic rat hearts. Am. J. Physiol., 264, H1884-H1889.

CHAMLEY, J.H., CAMPBELL, G.R., MCCONNELL, J.D. \& GROESCHEL-STEWART, U. (1977). Comparison of vascular smooth muscle cells from adult human, monkey and rabbit in primary culture and in subculture. Cell Tissue Res., 177, 503522.

CLARK, C.J., MILligAN, G., MCLELLAN, A.R. \& CONNELL, J.M.C (1993). Guanine nucleotide regulatory proteins in the spontaneously hypertensive rat. Hypertension, 21, 204-209.

COLLIS, M. \& HOURANI, S.M.O. (1993). Adenosine receptor subtypes. Trends Pharmacol. Sci., 14, 360-366.

DANTHULURI, N.R., \& DETH, R.C. (1989). Effects of intracellular alkalization on resting and agonist-induced vascular tone. Am.J. Physiol., 256, H867-H875.

ENGLAND, S.K. WOOLDRIDGE, T.A., STEKIEL, W.J. \& RUSCH, N.J. (1993). Enhanced single-channel $\mathrm{K}^{+}$current in arterial membranes form genetically hypertensive rats. Am. J. Physiol., 264, H1337-H1345.

FURUKAWA, K.-I., OHSHIMA, N., TAWADA-IWATA, Y. \& SHIGEKAWA, M. (1991). Cyclic GMP stimulates $\mathrm{Na}^{+} / \mathrm{Ca}^{2+}$ exchange in vascular smooth muscle cells in primary culture. J. Biol. Chem., 266, 12337-12341.

GARDNER, J.P. \& DIECKE, F.P.J. (1988). Influence of $\mathrm{pH}$ on isometric force development and relaxation in skinned vascular smooth muscle. Pflügers Arch., 412, 231-239.

GASKELL, W.H. (1880). On the tonicity of the heart and blood vessels. J. Physiol., 3, 48-75. 
GRIFFITH, S.L., THOADES, R.A. \& PACKER, C.S. (1994). Pulmonary arterial smooth muscle contractility in hypoxia-induced pulmonary hypertension. J. Appl. Physiol., 77, 406-414.

HARDER, D.R. (1982). Membrane electrical activation of arterial smooth muscle. In Vascular Smooth Muscle: Metabolic, Tonic and Contractile Mechanisms, ed. Crass, M.F., III \& Barnes, C.D., pp. 71 -97. New York: Academic Press.

HISADA, T., SINGER, J.J. \& WALSH, J.V., JR. (1993). Aluminofluoride activates hyperpolarization- and stretch-activated cationic channels in single smooth muscle cells. Pflügers Arch., 422, 397-400.

IKEDA, K., GUTIERREZ, U.G., JR. \& YAMORI, Y. (1992). Dietary $N^{\mathrm{G}}$-nitro-L-arginine induces sustained hypertension in normotensive Wistar-Kyoto rats. Clin. Exp. Pharmacol. Physiol., 19, $583-586$.

JAISWAL, N., JAISWAL, R.K., TALLANT, A., DIZ, D.I. \& FERRARIO, C.M. (1993). Alterations in prostaglandin production in spontaneously hypertensive rat smooth muscle cells. Hypertension, 21, 900-905.

JONES, A.W. (1982). In Vascular Smooth Muscle: Metabolic, Ionic and Contractile Mechanisms ed. Crass, M.F., III \& Barnes, C.D., pp. 37-70, New York: Academic Press.

KARAKI, H. (1989). $\mathrm{Ca}^{2+}$ localization and sensitivity in vascular smooth muscle. Trends Pharmacol. Sci., 10, 320-325.

KIRBER, M.T., WALSH, J.V. JR. \& SINGER, J.J. (1988). Stretchactivated ion channels in smooth muscle: a mechanism for the initiation of stretch-induced contraction. Pflügers Arch., 412, $339-345$.

KULIK, T.J., ALVARADO, S.P. (1993). Effect of stretch on growth and collagen synthesis in cultured rat and lamb pulmonary arterial smooth muscle cells. J. Cell Physiol., 157, 615-624.

KURTZ, I. \& GOLCHINI, K. (1987). $\mathrm{Na}^{+}$-independent $\mathrm{Cl}^{-}-\mathrm{HCO}_{3}^{-}$ exchange in Madin-Darby canine kidney cells. Role in intracellular pH regulation. J. Biol. Chem., 262, 4516-4520.

KUTTAN, S.C. \& SIM, M.K. (1993). Angiotensin II-induced tachyphylaxis in aortas of normo- and hyptertensive rats: changes in receptor affinity. Eur. J. Pharmacol., 232, 173-180.

LAXSON, D.D., HOMANS, D.C., BACHE, R.J. (1993). Inhibition of adenosine-mediated coronary vasodilation exacerbates myocardial ischemia during exercise. Am. J. Physiol., 265, H1471H1477.

LE JEMTEL, T.H., LAMBERT, F., LEVITSKY, D.O., CLERGUE, M., ANGER, M., GABBIANI, G. \& LOMPRE, A.-M. (1993). Age-related changes in sarcoplasmic reticulum $\mathrm{Ca}^{2+}$-ATPase and $\alpha$-smooth muscle actin gene expression in aortas of normotensive and spontaneously hypertensive rats. Circ. Res., 72, 341-348.

LEVINE, R.L. (1993). Ischemia: from acidosis to oxidation. FASEB J., 7, $1242-1246$.

MITSUI, M. \& KARAKI, H. (1990). Dual effects of carbachol on cytosolic $\mathrm{Ca}^{2+}$ and contraction in intestinal smooth muscle. Am. J. Physiol., 258, C787-C793.

NAGESETTY, R. \& PAUL, R.J. (1995). Effects of $\mathrm{pH}_{\mathrm{i}}$ on isometric force and $\left[\mathrm{Ca}^{2+}\right]_{\mathrm{i}}$ in porcine coronary artery smooth muscle. Circ. Res., 75, 990-998.
NARUSE, K. \& SOKABE, M. (1993). Involvement of stretch-activated ion channels in $\mathrm{Ca}^{2+}$ mobilization to mechanical stretch in endothelial cells. Am. J. Physiol., 264, C1037-C1044.

NGAI, A.C. \& WINN, R. (1993). Effects of adenosine and its analogues on isolated intracerebral arterioles: extraluminal and intraluminal application. Circ. Res., 73, 448-457.

ORLOV, S., RESINK, T.J., BERNHARDT, J., FERRACIN, F. \& BUHLER, F.R. (1993). Vascular smooth muscle cell calcium fluxes - Regulation by angtiotensin II and lipoproteins. Hypertension, 21, 195-203.

ROSSKOPF, D., DUSING, R. \& SIFFERT, W. (1993). Membrane sodium-proton exchange and primary hypertension. Hypertension, 21, 607-617.

RUDOLPHI, K.A., SCHUBERT, P., PARKINSON, F.E. \& FREDHOLM, B.B. (1992). Neuroprotective role of adenosine in cerebral ischemia. Trends Pharmacol. Sci., 13, 439-445.

SCHIRNER, M. \& TAUBE, C. (1993). Different effects of aspirin on blood pressure of spontaneously hypertensive rats (SHR) with high and spontaneously low levels of blood pressure. Br. J. Pharmacol., 109, 900-901.

SCHWARTZKOPF, B., MOTZ, W., VOGT, M. \& STRAUER, B.E. (1993). Heart failure on the basis of hypertension. Circulation, 87, Suppl.4: IV66 - IV72.

SHIDA, M. \& ISOYAMA, S. (1993). Effects of age on c-fos and c-myc gene expression in response to hemodynamic stress in isolated, perfused rat hearts. J. Mol. Cell. Cardiol., 25, 1025-1035.

SIMS, P.J., WAGGONER, A.S., WANG, C.-H. \& HOFFMAN, J.F. (1974) Studies on the mechanism by which cyanine dyes measure membrane potential in red blood cells and phosphatidylcholine vesicles. Biochemistry, 13, 3315-3330.

SOFOLA, O.A., OBIEFUNA, P.C.M. \& ADEGUNLOYE, B.J. (1993). Contractile response of normotensive rat aorta to serum from salt-loaded Sprague-Dawley rats. Pflügers Arch., 423, 161-163.

SOMLYO, A.P. (1985). Excitation-contraction coupling and the ultrastructure of smooth muscle. Circ. Res., 57, 497-507.

STERPETTI, A.V., CUCINA, A., D'ANGELO, L.S., CARDILlO, B. CAVALlARO, A. (1993). Shear stress modulates the proliferation rate, protein synthesis and mitogenic activity of arterial smooth muscle cells. Surgery, 113, 691-699.

SUZUKI, M., TAKAHASHI, K., IKEDA, M., HAYAKAWA, H., OGAWA, A., KAWAGUCHI, Y. \& SAKAI, O. (1994). Cloning of a pH-sensitive $\mathrm{K}^{+}$channel possessing two transmembrane segments. Nature, 367, 642-645.

YANAGISAWA, T., TESHIGAWARA, T. \& TAIRA, N. (1990) Cytoplasmic calcium and the relaxation of canine coronary arterial smooth muscle produced by cromakalim, pinacidil and nicorandil. Br. J. Pharmacol., 101, 157-165.

YANG, X.-C. \& SACHS, F. (1989). Block of stretch-activated ion channels in Xenopus oocytes by gadolinium and calcium ions. Science, 243, 1068-1071.

YU, J., ZHENG, J.J., ONG, B.Y. \& BOSE, R. (1991). Intracellular pH measurement with fluorescent dye in canine basilar arteries. Blood Vessels, 28, 464-474. 